\title{
PENGARUH TIPE BANGKITAN EPILEPSI TERHADAP HASIL PEMERIKSAAN CLOCK DRAWING TEST PASIEN EPILEPSI RAWAT JALAN DI RSJ MUTIARA SUKMA PROVINSI NTB
}

\author{
Artikel Penelitian \\ Annisa Firdausi Anwar', Herpan Syafii Harahap ${ }^{2}$, Emmy Amalia ${ }^{3}$ \\ ${ }^{1}$ Program Studi Sarjana Kedokteran, Fakultas Kedokteran Universitas Mataram \\ ${ }^{2}$ Departemen Neurologi, Fakultas Kedokteran Universitas Mataram \\ ${ }^{3}$ Departemen Psikiatri, Fakultas Kedokteran Universitas Mataram
}

Email : firdausi.anwar@gmail.com

\begin{abstract}
ABSTRAK
Gangguan kognitif merupakan salah satu dampak epilepsi yang dapat dipengaruhi oleh tipe bangkitan. Clock Drawing Test (CDT) merupakan uji yang mudah dan sederhana dalam menilai banyak domain kognitif sehingga populer digunakan sebagai uji penapisan. Belum ada penelitian yang menggunakan CDT dalam menilai pengaruh tipe bangkitan terhadap gangguan kognitif pasien epilepsi sehingga ini merupakan penelitian yang pertama. Penelitian ini bertujuan untuk menganalisis pengaruh tipe bangkitan epilepsi terhadap fungsi kognitif global yang dinilai dengan hasil pemeriksaan CDT pada pasien epilepsi rawat jalan di Rumah Sakit Jiwa Mutiara Sukma. Penelitian ini menggunakan pendekatan studi potong lintang. Pengambilan data bertempat di Poli Saraf Rumah Sakit Jiwa Mutiara Sukma Provinsi Nusa Tenggara Barat dalam periode waktu Agustus 2016-Agustus 2017. Uji Chi-square atau Fisher-exact digunakan untuk menguji signifikansi antara tipe bangkitan dan fungsi kognitif global. Terdapat $60,9 \%$ pasien yang memiliki tipe bangkitan general dengan $4 \%$ memiliki fungsi kognitif normal dan 96\% terganggu. Tipe bangkitan fokal sebesar 39,1\% dengan 15,4\% memiliki fungsi kognitif normal dan 84,6\% terganggu. Tidak terdapat pengaruh tipe bangkitan epilepsi terhadap hasil pemeriksaan Clock. Drawing Test (CDT) pada pasien epilepsi rawat jalan di Rumah Sakit Jiwa Mutiara Sukma ( $>>0,05)$
\end{abstract}

Kata Kunci : epilepsi, tipe bangkitan, kognitif, CDT

\section{ABSTRACT}

Cognitive impairment is one of the consequence of epilepsy affected by factors such as seizure type. Clock. Drawing Test (CDT) has been popular as a screening test due to it quick and easy way to measure many cognitive domains. No research has been used CDT to evaluate seizure type effect to cognitive impairment in epilepsy patient, this is the first research to do that. This research aimed to analyze the effect of seizure type in cognitive global function measured by the result of CDT examination in epilepsy outpatient clinic at Mutiara Sukma Mental Health Hospital. This research is a cross-sectional study. Data were collected at Neurology Center of Mutiara Sukma Mental Health Hospital between August 2016-August 2017. Chi-square test or Fisher-exact test used to find signification between seizure type and global cognitive function. There were $60.9 \%$ patients who had generalized seizures with $4 \%$ having normal cognitive function and $96 \%$ baving impaired. Focal seizure type was 39.1\% with 15.4\% having normal cognitive function and 84.6\% having impaired. There is no effect of seizure type in the result of Clock Drawing Test (CDT) examination in epilepsy outpatient at Mutiara Sukma Mental Health Hospital $(p>0,05)$

Keywords : epilepsy, seizure type, cognitive, CDT 


\section{PENDAHULUAN}

Terdapat sekitar 1,5 juta orang penderita epilepsi dari 230 juta penduduk Indonesia (Muttaqin, 2012). Data tahun 2016 menunjukkan pasien epilepsi rawat jalan di Rumah Sakit Jiwa Mutiara Sukma Provinsi Nusa Tenggara Barat sebesar 47,6\% dari seluruh pasien saraf rawat jalan (Komite Peningkatan Mutu dan Keselamatan Pasien RSJ Mutiara Sukma, 2016). Melihat tingginya jumlah penderita epilepsi, maka penting untuk mengetahui dampak yang ditimbulkan.

Epilepsi memiliki dampak yang cukup besar seperti masalah belajar, gangguan psikologis dan gangguan perilaku. Penderita epilepsi yang tidak terkontrol dengan baik juga dapat memiliki dampak yang jauh lebih kompleks seperti defisit motorik dan gangguan tidur (Scheffer et al, 2017). Dampak penurunan fungsi kognitif pada penderita epilepsi dipengaruhi oleh faktor etiologi, usia onset bangkitan, tipe bangkitan, tingkat keparahan, durasi, pengobatan dan faktor lain (Herman dan Seidenberg, 2007; Nehra et al, 2013). Tatalaksana lebih awal dapat mengurangi dampak tersebut. Hal ini dapat dilakukan jika diagnosis ditegakkan lebih dini, salah satunya dengan mengenali tipe bangkitan epilepsi.

Tipe bangkitan epilepsi diklasifikasikan menjadi tipe bangkitan fokal, tipe bangkitan general, dan tipe bangkitan yang tidak diketahui (Fisher et al., 2017). Penelitian sebelumnya memperlihatkan gangguan kognitif yang lebih buruk pada pasien dengan tipe bangkitan general (Huang et al, 2005) Namun penelitian lain menunjukkan bahwa penderita epilepsi tipe bangkitan fokal cenderung lebih buruk pada semua tes fungsi kognitif dibandingkan dengan tipe bangkitan general (Liik et al, 2013) Hasil yang berbeda ini menjadi dasar untuk mencari pengaruh tipe bangkitan terhadap fungsi kognitif lebih lanjut.

Uji skrining untuk mengevaluasi fungsi kognitif pada penderita epilepsi dapat dilakukan dengan pemeriksaan The Montreal Cognitive Assessment versi Indonesia (MoCA-INA), Mini Mental State Examination (MMSE) dan Clock Drawing Test (CDT). Pemeriksaan CDT memiliki keunggulan daripada uji lainnya dari segi waktu yang digunakan untuk mengerjakan pemeriksaan kurang dari 10 menit, penguji tidak membutuhkan kompetensi khusus sehingga dapat dilakukan oleh mahasiswa, dan domain kognitif yang dinilai lebih banyak. CDT menjadi penilaian skrining kognitif yang mudah dan sederhana sehingga menjadi perangkat yang populer dalam praktik klinik maupun penelitian (Shulman, 2000; Brodaty dan Moore, 1997; Ferrucci et al, 1996). Sampai saat ini belum ada penelitian yang menggunakan CDT dalam mengevaluasi pengaruh tipe bangkitan terhadap fungsi kognitif global pasien epilepsi sehingga ini menjadi penelitian yang pertama.

Penelitian ini dilakukan dengan tujuan untuk menganalisis pengaruh tipe bangkitan terhadap hasil pemeriksaan Clock Drawing Test (CDT) pada pasien epilepsi rawat jalan di Rumah Sakit Jiwa Mutiara Sukma Provinsi Nusa Tenggara Barat. RSJ Mutiara Sukma merupakan salah satu tempat rujukan pasien epilepsi di tingkat provinsi selain Rumah Sakit Umum Provinsi. RSJ Mutiara Sukma memiliki kemudahan akses, tingkat kunjungan pasien yang tinggi, dan memiliki klinik memori untuk evaluasi fungsi kognitif. Penelitian ini juga dilakukan sebagai langkah awal penelitian epilepsi di Nusa Tenggara Barat.

\section{METODE PENELITIAN}

Penelitian ini menggunakan metode analitik observasional dengan pendekatan studi potong lintang. Sampel terpilih merupakan pasien epilepsi rawat jalan di Rumah Sakit Jiwa Mutiara Sukma pada Agustus 2016 hingga Agustus 2017. Sampel pada penelitian ini diambil dengan cara non-probability sampling menggunakan teknik consecutive random sampling dan sebanyak 64 orang memenuhi kriteria sebagai subjek penelitian.

Tipe bangkitan epilepsi adalah epilepsi tipe bangkitan fokal dan general sesuai klasifikasi ILAE tahun 2017 yang didapatkan dari hasil anamnesis (Fisher et al., 2017). Fungsi kognitif global pasien epilepsi dinilai dari hasil pemeriksaan Clock Drawing Test (CDT) yang dinyatakan sebagai normal jika skor 4 dan terganggu jika skor kurang dari 4. Karakteristik demografi dan klinis pasien didapat dari lembar kuisioner identitas responden. Uji nonparametrik chi-square atau Fisher-exact digunakan untuk menguji pengaruh tipe bangkitan terhadap fungsi kognitif global yang dinilai dari hasil pemeriksaan CDT pasien. 


\section{HASIL PENELITIAN}

Jumlah subjek dalam penelitian ini sebanyak 64 orang dengan tipe bangkitan general sebanyak 39 orang $(60,9 \%)$ dan tipe bangkitan fokal sebanyak 25 orang $(39,1 \%)$. Hasil pemeriksaan fungsi kognitif global yang dinilai dengan skor Clock Drawing Test (CDT) memperlihatkan 7 orang memiliki jumlah skor CDT 4 yang berarti fungsi kognitif normal $(10,9 \%)$ dan 57 orang memiliki jumlah skor CDT kurang dari 4 yang berarti mengalami gangguan fungsi kognitif $(89,1 \%)$. Karakteristik pasien yang memiliki pengaruh bermakna terhadap fungsi kognitif global adalah onset bangkitan, sehingga terdapat perbedaan bermakna fungsi kognitif global pada pasien epilepsi dengan onset bangkitan usia kurang dari 20 tahun dan pasien epilepsi dengan onset bangkitan usia 20 tahun atau lebih. Jenis kelamin, etiologi, obat anti epilepsi, usia, lama pendidikan, lama pengobatan, dan lama terdiagnosis epilepsi tidak memiliki pengaruh yang bermakna terhadap fungsi kognitif global $(\mathrm{P}>0,05)$. Karakteristik pasien dapat dillhat dalam Tabel 1.

Tabel 1. Pengaruh Karakteristik Subjek Terhadap Fungsi Kognitif Global

\begin{tabular}{|c|c|c|c|c|c|}
\hline \multirow{2}{*}{\multicolumn{2}{|c|}{ Karak teristik Subjek Penelitian }} & \multicolumn{3}{|c|}{ Fungsi Kognitif Global } & \multirow{2}{*}{$\begin{array}{c}P \\
\text { value }\end{array}$} \\
\hline & & & \multirow{2}{*}{$\begin{array}{c}\begin{array}{c}\text { Normal } \\
(n=7)\end{array} \\
5(17,9 \%)\end{array}$} & \multirow{2}{*}{$\begin{array}{c}\begin{array}{c}\text { Terganggu } \\
(\mathrm{n}=57)\end{array} \\
23(82,1 \%)\end{array}$} & \\
\hline Jenis Kelamin & Perempuan & $\mathrm{n}(\%)$ & & & 0225 \\
\hline & Laki-laki & $\mathrm{n}(\%)$ & $2(5,6 \%)$ & $34(94,4 \%)$ & 0,225 \\
\hline \multirow[t]{2}{*}{ Onset Bangkitan } & $<20$ tahun & $\mathrm{n}(\%)$ & $7(17,5 \%)$ & $33(82,5 \%)$ & \multirow{2}{*}{0,039} \\
\hline & $=20$ tahun & $\mathrm{n}(\%)$ & $0(0 \%)$ & $24(100 \%)$ & \\
\hline \multirow[t]{4}{*}{ Etiologi } & Trauma & $\mathrm{n}(\%)$ & $2(16,7 \%)$ & $10(83,3 \%)$ & \multirow{4}{*}{0,275} \\
\hline & Stroke & $\mathrm{n}(\%)$ & $0(0 \%)$ & $3(100 \%)$ & \\
\hline & Infeksi & $\mathrm{n}(\%)$ & $0(0 \%)$ & $1(100 \%)$ & \\
\hline & Idiopatik & $\mathrm{n}(\%)$ & $5(10,4 \%)$ & $43(89,6 \%)$ & \\
\hline \multirow[t]{2}{*}{ Obat Anti Epilepsi } & Monoterapi & $\mathrm{n}(\%)$ & $5(10,9 \%)$ & $41(89,1 \%)$ & \multirow{2}{*}{0,978} \\
\hline & Politerapi & $\mathrm{n}(\%)$ & $2(11,1 \%)$ & $16(88,9 \%)$ & \\
\hline \multirow[t]{2}{*}{ Tingkat Pendidikan } & $<12$ tahun & $\mathrm{n}(\%)$ & $4(10,8 \%)$ & $33(89,2 \%)$ & \multirow{2}{*}{1,000} \\
\hline & $=12$ tahun & $\mathrm{n}(\%)$ & $3(11,1 \%)$ & $24(88,9 \%)$ & \\
\hline Usia dalam tahun & & $\mathrm{x} \pm \mathrm{SD}$ & $23,86 \pm 7,381$ & $35,86 \pm 14,909$ & 0,054 \\
\hline \multicolumn{2}{|c|}{ Lama Pengobatan dalam bulan } & $\mathrm{x} \pm \mathrm{SD}$ & $70,29 \pm 40,652$ & $81,45 \pm 98,084$ & 0,275 \\
\hline \multicolumn{2}{|c|}{ Lama Terdiagnosis Epilepsi dalam tahun } & $\mathrm{x} \pm \mathrm{SD}$ & $11,57 \pm 4,791$ & $11,06 \pm 9,867$ & 0,311 \\
\hline
\end{tabular}

Perbedaan hasil pemeriksaan Clock

Drawing Test (CDT) pada dua kelompok tipe bangkitan epilepsi setelah dilakukan uji Fisher-Exact didapatkan $\mathrm{P}=0,231$ sehingga tidak ada perbedaan yang bermakna antara fungsi kognitif global pada pasien epilepsi dengan tipe bangkitan general dan pasien epilepsi dengan tipe bangkitan fokal $(\mathrm{P}>0,05)$. Hasil ini dapat dillhat dalam Tabel 2.

Tabel 2. Pengaruh Tipe Bangkitan Epilepsi Terhadap Fungsi Kognitif Global

\begin{tabular}{|c|c|c|c|c|c|}
\hline \multirow{2}{*}{\multicolumn{2}{|c|}{ Karakteristik Subjek Penelitian }} & & \multicolumn{2}{|c|}{ Fungsi Kognitif Global } & \multirow[b]{2}{*}{ Pvalue } \\
\hline & & & $\begin{array}{c}\text { Normal } \\
(\mathrm{n}=7)\end{array}$ & $\begin{array}{c}\text { Terganggu } \\
(\mathrm{n}-57)\end{array}$ & \\
\hline \multirow[t]{2}{*}{ Tipe Bangkitan } & Fokal & $\mathrm{n}(\%)$ & $1(4 \%)$ & $24(96 \%)$ & \multirow{2}{*}{0,231} \\
\hline & General & $\mathrm{n}(\%)$ & $6(15,4 \%)$ & $33(84,6 \%)$ & \\
\hline
\end{tabular}

Nilai $\mathrm{p}$ bermakna jika $\mathrm{p}<0,05$ 


\section{DISKUSI}

Hasil penelitian ini tidak sesuai dengan penelitian yang mengatakan bahwa tipe bangkitan epilepsi dapat mempengaruhi penurunan fungsi kognitif (Hermann dan Seidenberg, 2007; Helmstaedter, 2013), dan penelitian yang mengatakan gangguan kognitif terjadi lebih buruk pada pasien dengan tipe bangkitan general (Huang et al, 2005), maupun penelitian yang mengatakan bahwa pasien epilepsi tipe bangkitan fokal cenderung lebih buruk pada semua tes fungsi kognitif (Liik et al, 2013). Namun sesuai dengan penelitian lain yang menyatakan tipe bangkitan epilepsi tidak mempengaruhi fungsi kognitif pasien dengan epilepsi (Sunmonu et al, 2008). Perbedaan hasil ini dapat diakibatkan karena pengaruh karakteristik pasien, kapasitas brain reserve dan cognitive reserve yang berbeda antara setiap orang, kesalahan dalam mengenali tipe bangkitan dan faktor-faktor lain yang akan dijelaskan lebih lanjut dalam pembahasan ini.

Karakteristik pasien berupa onset bangkitan memiliki pengaruh terhadap kognitif $(\mathrm{P}=0,039)$. Onset bangkitan merupakan usia pertama kali subjek penelitian mengalami bangkitan epilepsi. Onset bangkitan dibagi menjadi usia kurang dari 20 tahun dan usia 20 tahun atau lebih untuk membedakan epilepsi onset usia anak-anak dengan onset usia dewasa (Marini et al., 2003). Anak dengan epilepsi tipe bangkitan fokal idiopatik dan anak dengan epilepsi tipe bangkitan general primer sama-sama memiliki gangguan fungsi kognitif yang ringan sekitar 10 bulan setelah onset bangkitan (Herman dan Seidenberg, 2007). Hal ini menjelaskan tidak adanya perbedaan penurunan fungsi kognitif antara bangkitan general dan fokal setelah bangkitan pertama kali.

Tipe bangkitan epilepsi menyebabkan perubahan struktur otak yang berbeda antara tipe bangkitan fokal dengan tipe bangkitan general. Apabila bangkitan berlangsung cukup lama dan terjadi secara berulang dalam waktu yang lama dapat menyebabkan kematian neuron, terutama pada orang dewasa. Bangkitan yang relatif singkat seperti tipe absans pada anak-anak yang berlangsung 5-10 detik tampak tidak menyebabkan kerusakan otak (Dingledine, 2015). Bangkitan fokal berlangsung cukup lama dibandingkan dengan bangkitan general sehingga memiliki resiko kematian neuron yang lebih besar dan gangguan kognitif yang lebih berat (Dobesberger et al, 2015).

Tipe neuron yang terkena dampak bangkitan merupakan neuron utama glutamatergik seperti sel piramidal korteks dan subpopulasi interneuron GABAergic (Dingledine, 2015). Bangkitan fokal berasal dari satu area fokal korteks serebral dan dapat menyebar ke daerah kortikal lainnya baik secara unilateral atau secara bilateral (Rudzinski dan Shih, 2010). Bangkitan general menyebabkan aktivitas listrik abnormal pada semua bagian korteks serebral secara bersamaan sehingga dianggap bahwa stimuli bangkitan ini timbul di luar korteks yaitu di formasio retikularis (Reeves dan Swenson, 2008). Bangkitan berulang dapat menyebabkan kerusakan otak yang cukup besar di daerah yang sangat rentan seperti bagian hipokampus, korteks di daerah lobus temporal medial (entorbinal), amigdala, talamus dan struktur limbik lainnya. Hal ini sering terjadi pada epilepsi lobus temporal yang merupakan tipe bangkitan fokal yang umum didapatkan di klinis (Jehi, 2012; Bertram, 2014).

Meskipun bangkitan fokal memiliki resiko kerusakan neuron yang lebih besar dari bangkitan general, namun penelitian ini tidak dapat menilai tingkat kerusakan neuron pada kedua tipe bangkitan karena tidak dilakukan pemeriksaan neuroimaging. Selain itu terdapat peran dari kapasitas brain reserve dan cognitive reserve yang mempengaruhi tingkat kerusakan neuron dan kompensasinya. Kapasitas brain reserve adalah ketahanan otak terhadap perubahan patologis. Semakin besar kapasitas brain reserve, semakin kecil kemungkinan individu mengalami gangguan perilaku yang terkait dengan suatu penyakit (Getz, 2011). Brain reserve mengacu pada karakteristik seperti volume otak, jumlah neuron dan jumlah sinaps. Terdapat perbedaan kapasitas brain reserve setiap individu yang menyebabkan perbedaan tingkat kerusakan pada otak Tingkat pendidikan yang tinggi, partisipasi dalam aktivitas tertentu, status sosioekonomi yang tinggi, dan kecerdasan dasar yang dimiliki dapat melindungi dari dampak kerusakan otak, hal ini dikenal sebagai cognitive reserve (Stern, 2009; Fotenos et al, 2008).

Kesalahan dalam mengenali tipe bangkitan dapat menyebabkan tidak terdapatnya perbedaan gangguan fungsi kognitif bangkitan general dan fokal. Penentuan tipe bangkitan yang mengandalkan informasi dari anamnesis tanpa ketersediaan tes 
diagnostik yang memadai sering menyebabkan kesalahan dalam mengenali tipe bangkitan fokal sebagai tipe bangkitan general (Banerjee et al, 2009). Kesalahan ini dapat disebabkan oleh pasien sendiri, keluarga atau orang lain yang menjelaskan bangkitan pasien, dan dari peneliti yang melakukan anamnesis. Seorang saksi perlu mengumpulkan informasi yang cukup mengenai bangkitan pasien karena dalam banyak kasus pasien epilepsi tidak sadar tentang apa yang terjadi selama bangkitan (Enrique de la Cal et al, 2016).

Faktor lain yang dapat mempengaruhi fungsi kognitif pasien epilepsi adalah kondisi komorbid. Anak-anak dengan epilepsi mengalami peningkatan resiko terkena gangguan Attention Deficit Hyperactivity Disorder (ADHD). Prevalensi ADHD tersebut tidak bervariasi menurut tipe bangkitan fokal maupun tipe bangkitan general. Adanya ADHD pada pasien epilepsi dapat menimbulkan dampak pada fungsi kognitif karena fungsi atensi dapat mempengaruhi aspek kognisi lainnya seperti memori, bahasa, dan pemecahan masalah (Schubert, 2005). Depresi pada pasien epilepsi dapat mempengaruhi fungsi kognitif. Gejala depresi lebih sering terjadi pada pasien epilepsi dengan fokus di lobus temporal dibandingkan dengan epilepsi diluar lobus temporal atau epilepsi dengan tipe bangkitan general (Garcia, 2012). Kualitas tidur yang buruk pada penderita depresi dapat berpengaruh buruk pada banyak domain kognitif. Selain kualitas tidur, obat anti depresi dan psikoterapi juga dapat berpengaruh terhadap fungsi kognitif (Lam et al, 2014).

\section{KESIMPULAN}

Dalam penelitian ini tidak terdapat pengaruh tipe bangkitan epilepsi terhadap fungsi kognitif global pasien epilepsi rawat jalan di Rumah Sakit Jiwa Mutiara Sukma Provinsi Nusa Tenggara Barat yang dinilai dengan hasil pemeriksaan Clock Drawing Test (CDT).

\section{DAFTAR PUSTAKA}

Banerjee, P. N. et al., 2009, The descriptive epidemiology of epilepsy - a review, Epilepsy Research, 85(1), pp. 31-45. Available from: https://www.ncbi.nlm.nih.gov/pmc/ articles/PM C2696575/pdf/ nihms102481.pdf
Bertram, E. H., 2014, Extratemporal lobe circuits in temporal lobe epilepsy, Epilepsy and Behavior, vol. 38, pp. 13-18,

Brodaty, H., Moore, C. M., 1997, The Clock Drawing Test for Dementia of the Alzheimer Type/ : a Comparison of Three Scoring Methods, International Journal, 12(11), pp. 619-627.

Dingledine, R. et al, 2014, When and How Do Seizures Kill Neurons, and Is Cell Death Relevant to Epileptogenesis? Advances in Experimental Medicine and Biology, 813, 109122. Available from: https:// www.ncbi.nlm.nih.gov/pmc/articles/ PMC4624106/pdf/nihms-727141.pdf

Dobesberger, J. et al., 2015, Duration of focal complex, secondarily generalized tonic-clonic, and primarily generalized tonic-clonic seizures - A video-EEG analysis, Epilepsy and Behavior, 49, pp. 111-117. doi: 10.1016/ j.yebeh.2015.03.023.

Enrique de la Cal, Jose R. et al, 2016, A platform for enhancing the Epilepsy Anamnesis\} Available from: di002.edv.uniovi.es/ villar/ Jose_R._Villar/Conference.../ delacalIWBBIO201..pdf

Ferrucci, L. et al., 1996, Does the Clock Drawing Test Predict Cognitive Decline in Older Persons Independent of the Mini-Mental State Examination?, pp. 1326-1331. Available from: http://onlinelibrary.wiley.com/doi/ 10.1111/j.1532-5415.1996.tb01403.x/abstract

Fisher, R. S. et al., 2017, Operational classification of seizure types by the International League Against Epilepsy/ : Position Paper of the ILAE Commission for Classification and Terminology, pp. 1-9. Available from: http:/ /onlinelibrary.wiley.com/doi/10.1111/ epi.13670/abstract

Fotenos AF. et al, 2008, Brain Volume Decline in Aging Evidence for a Relation Between Socioeconomic Status, Preclinical Alzheimer Disease, and Reserve. Arch Neurol;;65(1):113120. Available from: http:// a r chneur.ja manetwork.com/ article.aspx?doi $=10.1001 /$ archneurol.2007.27

Garcia, C. S., 2012, Depression in Temporal Lobe Epilepsy: A Review of Prevalence, Clinical Features, and Management Considerations, Epilepsy Research and Treatment, 2012, pp. 112. Available from: http:// 
www.hindawi.com/journals/ert/2012/ 809843/

Getz G.E., 2011, Brain Reserve Capacity. In: Kreutzer J.S., DeLuca J., Caplan B. (eds) Encyclopedia of Clinical Neuropsychology. Springer, New York, NY. Available at:

Helmstaedter, C., 2013, The Impact Of Epilepsy On Cognitive Function, J Neurol Neurosurg Psychiatry 84 : e1. Available from: http:// jnnp.bmj.com/cgi/doi/10.1136/jnnp-2013306103.14

Hermann, B., Seidenberg, M., 2007, Epilepsy and Cognition. Epilepsy Currents, 7(1), 1-6. Available from: https:// www.ncbi.nlm.nih.gov/pubmed/17304341

https://link.springer.com/referenceworkentry/ 10.1007\%2F978-0-387-79948-3_1177

Huang CW, et al., 2005, Cognitive Performance in Cryptogenic epilepsy. Acta Neurological Scandinavia 112(4): 228-233.

Jehi, L. E., 2012, Cortico-thalamic connections and temporal lobe epilepsy: an evolving story, Epilepsy Currents, vol. 12, no. 5, pp. 203-204,

Komite Peningkatan Mutu dan Keselamatan Pasien RSJ Mutiara Sukma, 2016, Data Pasien Poli Klinik RSJ Mutiara Sukma. Mataram: RSJ Mutiara Sukma.

Lam, R. W. et al, 2014, Cognitive Dysfunction in Major Depressive Disorder: Effects on Psychosocial Functioning and Implications for Treatment. Canadian Journal of Psychiatry. Revue Canadienne de Psychiatrie, 59(12), 649-654.

Liik, M. et al, 2013, Cognitive profile and depressive symptoms in patients with epilepsy., Medicina (Kaunas, Lithuania), 49(6), pp. 254-61. Available from: http:// www.ncbi.nlm.nih.gov/pubmed/24248005.

Marini, C. et al, 2003, Idiopathic generalised epilepsy of adult onset: clinical syndromes and genetics, J Neurol Neurosurg Psychiatry, 74, pp. 192-197. Available from: http:// jnnp.bmj.com/content/74/2/192.full.pdf

Muttaqin, Z., 2012, Epilepsy Surgery in Indonesia/ : Achieving a Better Result with Limited Resources, Bali Medical Journal, 1(2), pp. 5763. Available at: http://ojs.unud.ac.id/ index.php/bmj/article/view/4545.

Reeves, A. G., Swenson, R. S., 2008, Disorders Of The Nervous System 5th ed. Ch.3, sec.21.
Rudzinski, LA. Shib, JJ., 2010, The classification of seizures and epilepsy syndromes. CONTINUUM: Lifelong Learning in Neurology: 16 (3-Epilepsy) p 15-35. doi: 10.1212/ 01.CON.0000368230.11492.d5.

Scheffer, I. E. et al, 2017, ILAE classification of the epilepsies: Position paper of the ILAE Commission for Classification and Terminology, Epilepsia, 58(4), pp. 512-521. Available from: http:// onlinelibrary.wiley.com/doi/10.1111/ epi.13709/full

Schubert R., 2005, Attention deficit disorder and epilepsy. Pediatr Neurol. Jan;32(1):1-10 DOI:http://dx.doi.org/10.1016/ j.pediatrneurol.2004.06.007

Shulman, K. I. et al., 1993, Clock drawing and dementia in the community: A longitudinal study, International Journal of Geriatric Psychiatry, 8(6), pp. 487-496. Available from: http:// onlinelibrary.wiley.com/doi/10.1002/ gps.930080606/abstract

Shulman, K. I., 2000, Clock Drawing: Is It the Ideal Cognitive Skrining Test?, International Journal of Geriatric Psychiatry, 15(3), pp. 548561. doi: 10.1002/1099$1166(200006) 15: 6<548:$ : A I D GPS242>3.0.CO;2-U.

Stern, Y., 2009, Cognitive Reserve. Neuropsychologia, 47 (10), 2015 - 2028. Available from: https:// www.ncbi.nlm.nih.gov/pmc/articles/ PMC2739591/pdf/nihms123775.pdf

Sunmonu Ta. et al, 2008, Seizure Variables And Cognitive Performance In Patients With Epilepsy. African Journal Of Neurological Science 27 (2) Available from: https:// w w w a a $\mathrm{ns}$. p a a n s.o r g / article.php3?id article $=283$ 